\title{
The effect of trimethylamine on atmospheric nucleation involving $\mathrm{H}_{2} \mathrm{SO}_{4}$
}

\author{
M. E. Erupe ${ }^{1}$, A. A. Viggiano ${ }^{2}$, and S.-H. Lee ${ }^{1}$ \\ ${ }^{1}$ Kent State University, Department of Chemistry and Biochemistry, Kent, Ohio 44240, USA \\ ${ }^{2}$ Air Force Research Laboratory, Hanscom Air Force Base, Massachusetts, USA
}

Received: 2 November 2010 - Published in Atmos. Chem. Phys. Discuss.: 12 November 2010

Revised: 16 May 2011 - Accepted: 17 May 2011 - Published: 20 May 2011

\begin{abstract}
Field observations and quantum chemical calculations have shown that organic amine compounds may be important for new particle formation involving $\mathrm{H}_{2} \mathrm{SO}_{4}$. Here, we report laboratory observations that investigate the effect of trimethylamine (TMA) on $\mathrm{H}_{2} \mathrm{SO}_{4}-\mathrm{H}_{2} \mathrm{O}$ nucleation made under aerosol precursor concentrations typically found in the lower troposphere $\left(\left[\mathrm{H}_{2} \mathrm{SO}_{4}\right]\right.$ of $10^{6}-10^{7} \mathrm{~cm}^{-3}$; [TMA] of 180-1350 pptv). The threshold $\left[\mathrm{H}_{2} \mathrm{SO}_{4}\right]$ needed to produce the unity $J$ was from $10^{6}-10^{7} \mathrm{~cm}^{-3}$ and the slopes of $\log$ $J$ vs. $\log \left[\mathrm{H}_{2} \mathrm{SO}_{4}\right]$ and $\log J$ vs. $\log$ [TMA] were 4-6 and 1, respectively, strikingly similar to the case of ammonia $\left(\mathrm{NH}_{3}\right)$ ternary nucleation (Benson et al., 2011). At lower $\mathrm{RH}$, however, enhancement in $J$ due to TMA was up to an order of magnitude greater than that due to $\mathrm{NH}_{3}$. These findings imply that both amines and $\mathrm{NH}_{3}$ are important nucleation species, but under dry atmospheric conditions, amines may have stronger effects on $\mathrm{H}_{2} \mathrm{SO}_{4}$ nucleation than $\mathrm{NH}_{3}$. Aerosol models should therefore take into account inorganic and organic base compounds together to fully understand the widespread new particle formation events in the lower troposphere.
\end{abstract}

\section{Introduction}

New particle formation (NPF) is a global phenomenon (Kulmala et al., 2004) that can impact the nature and amount of clouds through formation of cloud condensation nuclei (CCN) in the atmosphere (Merikanto, 2009). NPF therefore has important climate implications and an understanding of the aerosol nucleation processes (formation of solid or liquid particles from gas phase species) is vital in reducing the current uncertainties associated with climate-aerosol interac-

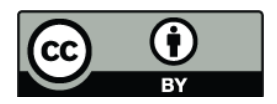

Correspondence to: S.-H. Lee (slee19@kent.edu) tions (IPCC, 2007). But the nucleation mechanisms are not well understood, and the identity of the possible species involved in the nucleation processes is yet unclear. Although several theories including binary homogeneous nucleation (BHN) (Vehkamäki et al., 2002) and ternary homogeneous nucleation (THN) with $\mathrm{NH}_{3}$ (Merikanto et al., 2007) have been proposed to explain nucleation in the atmosphere, most of them come short of reproducing the observed nucleation rates $(J)$ and the number of molecules in the critical cluster, especially at the typical conditions of the lower troposphere.

Laboratory experiments (Benson et al., 2008; Berndt et al., 2005; Sipilä et al., 2010; Young et al., 2008) and field observations (Erupe et al., 2010; Kulmala et al., 2004; Riipinen et al., 2007; Weber et al., 1999) have shown that $\mathrm{H}_{2} \mathrm{SO}_{4}$ is important in NPF in the atmosphere. However, other species are also needed to explain atmospherically observed $J$. Possible species include $\mathrm{NH}_{3}$ (Ball et al., 1999; Benson et al., 2009,2011 ) and volatile organic compounds (VOCs) such as organic acids (Bonn and Moortgat, 2003; Hoffmann et al., 1998; Kavouras et al., 1998; O'Dowd et al., 2002; Zhang et al., 2004), 1,3,5-trimethylbenzene (Paasonen et al., 2010), and amines (Barsanti et al., 2009; Smith et al., 2010). While there are thousands of organic compounds in the atmosphere, amines have become increasingly important, since recent quantum chemical calculations have shown that they can form neutral and ion clusters with $\mathrm{H}_{2} \mathrm{SO}_{4}$ molecules more efficiently than $\mathrm{NH}_{3}$ (Kurtén et al., 2008), even though amine concentrations are lower than that of $\mathrm{NH}_{3}$. This is further supported by a recent experiment which shows that amines can substitute ammonium to aminium in sub- $3 \mathrm{~nm}$ ammonium sulfate clusters (Bzdek et al., 2010). More evidence on the possible role of amines in NPF was found in field measurements which showed the presence of aminium ions in nanoparticles (Makela et al., 2001; Smith et al., 2004, 2008).

A comprehensive review of a large number of atmospheric amines including their thermodynamic properties was given by (Ge et al., 2010a, b). Amines are ubiquitous in the

Published by Copernicus Publications on behalf of the European Geosciences Union. 
atmosphere with various sources that include animal husbandry, oceans, waste incinerators and cars (Cadle and $\mathrm{Mu}-$ lawa, 1980; Facchini et al., 2008; Schade, 1995). Amines and $\mathrm{NH}_{3}$ in general have similar sources, and the relative abundance of amines vs. $\mathrm{NH}_{3}$ varies with sources and locations. For example, a study in the sea and remote location has shown that amines may contribute up to $20 \%$ of the concentration of the bases in these areas (Gibb et al., 1999), where $\mathrm{H}_{2} \mathrm{SO}_{4}$ forms from dimethylsulfide oxidation and thus nucleation also takes place. In the continental areas, animal husbandry produces up to $108 \mathrm{Gg} \mathrm{N} \mathrm{yr}^{-1}$ from TMA, which is 2 orders of magnitude lower that $\mathrm{NH}_{3}$ output (23 $300 \mathrm{Gg} \mathrm{N} \mathrm{yr}^{-1}$ ) (Schade, 1995). A more recent study has indicated that amines may represent up to $20 \%$ of the measured $\mathrm{NH}_{3}$ (Sorooshian et al., 2008). In terms of molecular structure, amines are classified into primary, secondary, or tertiary categories (Schade, 1995). Amongst tertiary amines, TMA is one of the most abundant species in the atmosphere and is one of the widely studied amine compounds (Schade, 1995; Silva et al., 2008).

There are also many similarities in the physical and chemical properties of TMA and $\mathrm{NH}_{3}$. TMA and $\mathrm{NH}_{3}$ compounds have similar basicities $\left(\mathrm{NH}_{3} \mathrm{pK}_{a}=9.25 ; \mathrm{TMApK}_{a}=10.72\right)$ and proton affinities $\left(\mathrm{PA}_{\mathrm{NH}_{3}}=853.6 \mathrm{~kJ} \mathrm{~mol}^{-1} ; \mathrm{PA}_{\mathrm{TMA}}=\right.$ $948.9 \mathrm{~kJ} \mathrm{~mol}^{-1}$ ), while Henry's law coefficients are somewhat different (TMA 9.5 $\mathrm{M} \mathrm{atm}^{-1}$ at $20^{\circ} \mathrm{C} ; \mathrm{NH}_{3} 60 \mathrm{M} \mathrm{atm}^{-1}$ at $25^{\circ} \mathrm{C}$ (NIST, 2005). Amines and $\mathrm{NH}_{3}$ can also lower the surface tension above the solution of $\mathrm{H}_{2} \mathrm{SO}_{4}$ and $\mathrm{H}_{2} \mathrm{O}$ and thus can potentially influence the Kelvin effect in homogeneous nucleation (Hyvarinen et al., 2004; Hyvärinen et al., 2005). Like $\mathrm{NH}_{3}$, amines are removed from the atmosphere by reactions with common atmospheric acids such as $\mathrm{H}_{2} \mathrm{SO}_{4}$ and $\mathrm{HNO}_{3}$. But unlike $\mathrm{NH}_{3}$, amines are also removed efficiently through rapid oxidation reactions with atmospheric oxidants, such as $\mathrm{OH}, \mathrm{O}_{3}$, and $\mathrm{NO}_{3}$ (FinlaysonPitts and Pitts, 2000; Ge et al., 2010a, b; Malloy et al., 2009; Murphy, 2007; Pitts Jr. et al., 1978). These similarities in sources and physical and chemical properties between $\mathrm{NH}_{3}$ and amines, and the fact that they both have been detected in atmospheric nanoparticles (Makela et al., 2001; Smith et al., 2005; Smith et al., 2008), make them ideal potential precursors for aerosol nucleation involving $\mathrm{H}_{2} \mathrm{SO}_{4}$. Currently, however, there are very few experimental studies involving amines and their possible roles in nucleation (Berndt et al., 2010; Smith et al., 2010; Wang et al., 2010a, b). Among these studies, only one study has so far examined the potential role of tert-butylamine (a primary amine) in nucleation (Berndt et al., 2010), while others have focused mainly on the possible roles of amines in the growth of newly formed particles.

In the present study, we have investigated the effect of TMA on $\mathrm{H}_{2} \mathrm{SO}_{4}-\mathrm{H}_{2} \mathrm{O}$ nucleation under $\left[\mathrm{H}_{2} \mathrm{SO}_{4}\right]$ of $10^{6}-10^{7}$ $\mathrm{cm}^{-3}$, to compare with $\mathrm{NH}_{3}-\mathrm{THNn}$ (Benson et al., 2011). Compared to the (Berndt et al., 2010) tert-butylamine study, the aerosol precursor concentrations $\left(\mathrm{H}_{2} \mathrm{SO}_{4}\right.$ and amines) used in the present study were one or three orders of magnitude lower, relevant to the real atmospheric conditions; $\mathrm{H}_{2} \mathrm{SO}_{4}$ was also detected directly by a chemical ionization mass spectrometer (CIMS). Particle formation rates as a function of $\left[\mathrm{H}_{2} \mathrm{SO}_{4}\right]$, [TMA] and $\mathrm{RH}$ were studied at a constant temperature $(288 \mathrm{~K})$. There is another companion paper by (Benson et al., 2011), where we show the effect of $\mathrm{NH}_{3}$ on $\mathrm{H}_{2} \mathrm{SO}_{4}$ nucleation under conditions relevant to the lower troposphere, as well as growth rates measured with CPC (TSI 3876) at low $\left[\mathrm{H}_{2} \mathrm{SO}_{4}\right]$ and possible factors which contribute to growth rates.

\section{Experiments}

Detailed description of the instruments and the performance was given elsewhere (Benson et al., 2008, 2009, 2011; Young et al., 2008). Only the details relevant to the current experiments are reported here. $\mathrm{OH}$ radicals were produced by photolyzing water vapor using UV light (wavelength $\lambda<$ $185 \mathrm{~nm}$ ) with a mercury lamp (Pen-Ray $11 \mathrm{SC}-1)$. The $\mathrm{OH}$ radicals then were mixed with $\mathrm{SO}_{2}, \mathrm{O}_{2}$, humidified $\mathrm{N}_{2}$ (to control $\mathrm{RH}$ ), dry $\mathrm{N}_{2}$ gases (vaporized from liquid nitrogen) and TMA, before they entered a temperature controlled fast flow reactor $(288 \mathrm{~K})$ where nucleation took place. $\mathrm{H}_{2} \mathrm{SO}_{4}$ vapor was produced from the

$\mathrm{SO}_{2}+\mathrm{OH} \rightarrow \mathrm{HSO}_{3}$

reaction, rate constant $k_{1}=8.8 \times 10^{-13} \mathrm{~cm}^{3} \mathrm{~s}^{-1}$, (FinlaysonPitts and Pitts, 2000) and was measured with CIMS, using $\left(\mathrm{HNO}_{3}\right) \mathrm{NO}_{3}^{-}$ions as reagent (Eisele and Tanner, 1993; Erupe et al., 2010). Variation in $\left[\mathrm{H}_{2} \mathrm{SO}_{4}\right]$ in the nucleation reactor was made by changing the slit width in the UV box using an iris beam splitter, which in turn changed the photon flux in the photolysis tube (Benson et al., 2011). This phototube current was also simultaneously measured by a picoammeter (Keithley 6485) and used to estimate $[\mathrm{OH}]$ produced based on (Cantrell et al., 1997; Young et al., 2008). From these $[\mathrm{OH}]$, we can estimate $\left[\mathrm{H}_{2} \mathrm{SO}_{4}\right]$ and thus, this method also serves as calibration of $\mathrm{H}_{2} \mathrm{SO}_{4}$-CIMS. We also added a second water bath after the UV source, to change $\mathrm{RH}$ independently from $[\mathrm{OH}]$ (and thus $\left[\mathrm{H}_{2} \mathrm{SO}_{4}\right]$ ) (Benson et al., 2011). The nucleation reactor had a diameter of $5.08 \mathrm{~cm}$ and a length of $80 \mathrm{~cm}$; and we assumed nucleation time is half of the residence time based on nucleation inversion modeling calculations (Young et al., 2008). The total flow inside the nucleation reactor was maintained at $2-5$ liters per minute (lpm), corresponding to a residence time of $\sim 20-50 \mathrm{~s}$.

Particle number concentrations were measured using a butanol-based condensation particle counter (CPC, TSI 3776). The cutting sizes of the CPC are $3 \mathrm{~nm}(100 \%$ detection efficiency), $2.3 \mathrm{~nm}(50 \%), 2 \mathrm{~nm}(25-30 \%)$ and 1.8 $\mathrm{nm} \quad(\sim 10 \%)$, (http://www.tsi.com/uploadedFiles/Product_ Information/Literature/Spec_Sheets/3776_2980346_A4.pdf). As shown in (Benson et al., 2011), the produced particles 
were smaller than $2 \mathrm{~nm}$ with $\left[\mathrm{H}_{2} \mathrm{SO}_{4}\right]$ of $10^{6}$ to $10^{7} \mathrm{~cm}^{-3}$, with the majority smaller than $1.8 \mathrm{~nm}$. The growth rates $\left(\sim 2.6-7.7 \mathrm{~nm} \mathrm{~h}^{-1}\right)$ estimated from CPC at these low $\left[\mathrm{H}_{2} \mathrm{SO}_{4}\right]$ were discussed in detail in (Benson et al., 2011).

To reduce possible impurities of $\mathrm{NH}_{3}$ in the system, $\mathrm{N}_{2}$ gases that were used for dilutions and makeup flows were vaporized from liquid nitrogen which has minimal $\mathrm{NH}_{3}$ (<20 pptv; $1 \mathrm{pptv} \approx 2 \times 10^{7} \mathrm{~cm}^{-3}$ ) (Benson et al., 2010; Nowak et al., 2006). All experimental setup was exclusively built with fluorinated ethylene propylene (FEP) or perfluoroalkoxy (PFA) Teflon surfaces, since $\mathrm{NH}_{3}$ adsorption is least effective on these Teflon materials and most effective on the stainless steel material (Benson et al., 2010; Nowak et al., 2007; Yokelson et al., 2003). The impurity $\mathrm{NH}_{3}$ likely originated from de-ionized water was also determined with CIMS and was below 100 pptv at RH 6-40\% (Benson et al., 2011).

TMA vapor was introduced from a previously calibrated, National Institute of Standard Technology (NIST) traceable disposable permeation tube kept at constant temperature $(303 \mathrm{~K})$ in a gas standard generator (Kin-tek 491MB), thereby emitting a uniform known amount of TMA at the ppbv range. Further dilutions were made at the mixing ratio in the range from $\sim 180-1350 \mathrm{pptv}$. TMA was introduced at $10 \mathrm{~cm}$ downstream of $\mathrm{SO}_{2}$ addition, corresponding to a reaction time of $0.7 \mathrm{~s}$. With this reaction time and $\left[\mathrm{SO}_{2}\right]$ of 4 ppmv, $100 \%$ of $\mathrm{OH}$ radicals are converted to $\mathrm{HSO}_{3}$ via Reaction (R1) (hence to $\mathrm{H}_{2} \mathrm{SO}_{4}$ ) in the photolysis region, assuming a homogeneous air mixing and negligible $\mathrm{CO}$ and hydrocarbons in the system. Moreover, at lower [TMA] level (sub-ppbv or ppbv) used in the current experiments, TMA did not affect the $[\mathrm{OH}]$ level to further alter $\left[\mathrm{H}_{2} \mathrm{SO}_{4}\right]$. The possibility that TMA oxidation by $\mathrm{OH}$ may form condensable products was further ruled out by running control experiments without adding $\mathrm{SO}_{2}$. Without $\mathrm{SO}_{2}$ and with TMA and $\mathrm{OH}$, we did not observe particle formation. The rate constant for the TMA + OH reaction is at the 3.6-6.1 $\times 10^{-11} \mathrm{~cm}^{3} \mathrm{~s}^{-1}$ range (Atkinson, 1986; Koch et al., 1996). It is possible that the TMA + $\mathrm{OH}$ oxidation products such as peroxides, alkyl peroxides and imines (Malloy et al., 2009; Murphy, 2007) may be too volatile to form particles in a short time scale (20-50 s) or these oxidation products may not form clusters easily as $\mathrm{H}_{2} \mathrm{SO}_{4}$ molecules.

We have used the TMA concentrations, provided by the permeation tube, in this study. Occasionally, TMA in the nucleation reactor was also verified using a CIMS, utilizing a detection scheme shown below, which is similar to that used for $\mathrm{NH}_{3}$ (Benson et al., 2010; Nowak et al., 2006)

$$
\begin{aligned}
& \left(\mathrm{CH}_{3}\right)_{3} \mathrm{~N}+\left(\mathrm{C}_{2} \mathrm{H}_{5} \mathrm{OH}\right)_{n} \mathrm{H}^{+} \rightarrow \\
& \left(\mathrm{CH}_{3}\right)_{3} \mathrm{~N} \cdot\left(\mathrm{C}_{2} \mathrm{H}_{5} \mathrm{OH}\right)_{n-m} \mathrm{H}^{+}+m\left(\mathrm{C}_{2} \mathrm{H}_{5} \mathrm{OH}\right)
\end{aligned}
$$

where $m=1,2,3 \ldots$ etc., and $m$ is also an integer which is less of equal to $n$. We have estimated the reaction rate of Reaction (R3) with trajectory calculations (Viggiano et al., 1982) $\left(1.23 \times 10^{-9} \mathrm{~cm}^{3} \mathrm{~s}^{-1}\right)$ and the average dipole orientation (ADO) theory (Baulch et al., 1982) $\left(1.01 \mathrm{v} 10^{-9} \mathrm{~cm}^{3} \mathrm{~s}^{-1}\right)$. Both values are within the same range as the reaction rate, determined experimentally $\left(1.17 \times 10^{-9} \mathrm{~cm}^{3} \mathrm{~s}^{-1}\right)$ (Keesee, 1986 \#1379). These values are also similar to the reaction rate of the $\mathrm{NH}_{3}$-ethanol system $\left(k_{4}=1.5 \times 10^{-9} \mathrm{~cm}^{3} \mathrm{~s}^{-1}\right)$ (Nowak et al., 2002), as expected:

$\mathrm{NH}_{3}+\left(\mathrm{C}_{2} \mathrm{H}_{5} \mathrm{OH}\right)_{n} \mathrm{H}^{+} \rightarrow$

$\mathrm{NH}_{3} \cdot\left(\mathrm{C}_{2} \mathrm{H}_{5} \mathrm{OH}\right)_{n-m} \mathrm{H}^{+}+m\left(\mathrm{C}_{2} \mathrm{H}_{5} \mathrm{OH}\right)$

As shown in Fig. 1a and $\mathrm{b}$, the product ion signals $\left[\left(\mathrm{CH}_{3}\right)_{3} \mathrm{NH}^{+}\right.$, mass 60; $\left(\mathrm{CH}_{3}\right)_{3} \mathrm{~N} \cdot\left(\mathrm{C}_{2} \mathrm{H}_{5} \mathrm{OH}\right) \mathrm{H}^{+}$, mass 106] show that [TMA] produced from the permeation tube was constant and stable. The possible impurities [TMA] in the nucleation tube were estimated to roughly $<\sim 85 \mathrm{ppbv}$ at low $\mathrm{RH}(<10 \%)$ conditions, but more systematic investigations are required in future studies. Due to such impurities of $\mathrm{NH}_{3}$ $(<100$ pptv) and amines (e.g., TMA $<85$ pptv) in the system, the experiments performed without adding TMA should be considered as a pseudo BHN system.

\section{Results}

One of the objectives of the present study was to compare the effects of TMA on $\mathrm{H}_{2} \mathrm{SO}_{4}$ nucleation with the $\mathrm{NH}_{3}$ effects reported in (Benson et al., 2011). And, our experimental results show that TMA acts very similarly to $\mathrm{NH}_{3}$. Figure 2a shows the results of $\log J$ vs. $\log \left[\mathrm{H}_{2} \mathrm{SO}_{4}\right]$ for $\mathrm{RH}$ between $12-41 \%$, $\left[\mathrm{H}_{2} \mathrm{SO}_{4}\right]$ between $3 \times 10^{6}-4 \times 10^{7} \mathrm{~cm}^{-3}$ and [TMA] of $480 \mathrm{pptv}$ at a temperature of $288 \mathrm{~K}$. These experimental conditions were close to those of (Benson et al., 2011); but the residence times were different in these two studies, 20-50 s in the current experiments and $190 \mathrm{~s}$ in (Benson et al., 2011). In the presence of 480 pptv TMA, $J$ was higher than in the absence of TMA, within the RH range studied (12-41\%), demonstrating that TMA indeed enhances nucleation of $\mathrm{H}_{2} \mathrm{SO}_{4}$ and $\mathrm{H}_{2} \mathrm{O}$ (Fig. 2a), similarly to $\mathrm{NH}_{3}$ (Benson et al., 2011).

In the absence of TMA, the slope of $\log J$ vs. $\log$ $\left[\mathrm{H}_{2} \mathrm{SO}_{4}\right]$ was between 4-6 and generally increased as the $\mathrm{RH}$ decreased, similarly to our previous laboratory studies of homogeneous nucleation (Benson et al., 2008, 2009; Young et al., 2008). Since the particle measurements with CPC have size dependent detection efficiencies and the formed particles also grow by condensation in addition to nucleation, the observed slope of $\log J$ vs. $\log \left[\mathrm{H}_{2} \mathrm{SO}_{4}\right]$ included both nucleation and condensation effects and condensation growth made the slope appear higher than the actual values. The $\left[\mathrm{H}_{2} \mathrm{SO}_{4}\right]$ needed to produce the unity $J$ (that is, threshold $\left[\mathrm{H}_{2} \mathrm{SO}_{4}\right]$ for nucleation) was about $4 \times 10^{6} \mathrm{~cm}^{-3}$. This is also similar to (Benson et al., 2011), despite the residence times being up to a factor of 5 lower in the present study. Thus, whereas residence time is important in nucleation as discussed in (Benson et al., 2011; Berndt et al., 2010), it 

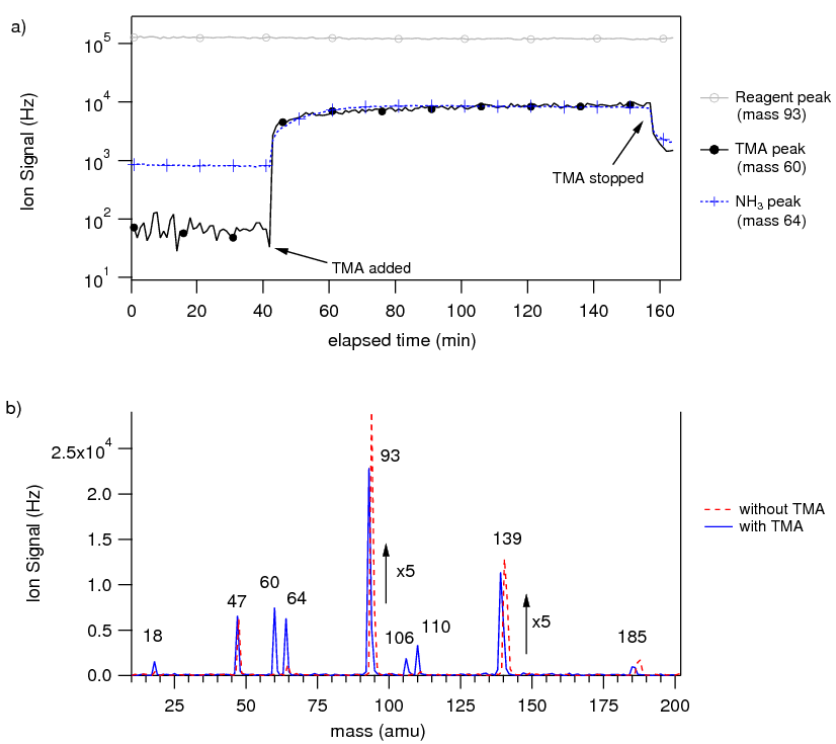

Fig. 1. (a) CIMS-measured TMA (black solid line and filled circles) and background $\mathrm{NH}_{3}$ originated from the TMA permeation tube (blue dotted line and crosses). This figure shows that the production of TMA from the permeation tube is steady with time, but $\mathrm{NH}_{3}$ impurities also exist from TMA. (b) A mass spectrum before and after adding $480 \mathrm{pptv}$ TMA. After addition of TMA, TMA ion peaks $\left[\left(\mathrm{CH}_{3}\right)_{3} \mathrm{NH}^{+}\right.$, mass $60 \mathrm{amu} ;\left(\mathrm{CH}_{3}\right)_{3} \mathrm{~N} \cdot\left(\mathrm{C}_{2} \mathrm{H}_{5} \mathrm{OH}\right) \mathrm{H}^{+}$, mass 106] were clearly observed. Also, $\mathrm{NH}_{3}$ peaks $\left[\left(\mathrm{NH}_{3}, \cdot\left(\mathrm{C}_{2} \mathrm{H}_{5} \mathrm{OH}\right) \mathrm{H}^{+}\right.\right.$, mass $64 ; \mathrm{NH}_{4}^{+}$, mass 18 ] increased, indicating that there were some $\mathrm{NH}_{3}$ impurities from the TMA source. The spectrum without TMA is right-shifted $2 \%$ and mass 93 and 139 are scaled down (5 times) for clarity. We have estimated up to $400 \mathrm{pptv}$ of $\mathrm{NH}_{3}$ impurities in the system (including those from TMA and de-ionized water).

has little effect on the cutoff of $\left[\mathrm{H}_{2} \mathrm{SO}_{4}\right]$ needed to produce the unity $J$, at least for the TMA case. The slope of Log $J$ vs. $\log \left[\mathrm{H}_{2} \mathrm{SO}_{4}\right]$ also slightly reduced by $1-2$ in the presence of TMA. This reduction in the slope of $\log J$ vs. $\log$ $\left[\mathrm{H}_{2} \mathrm{SO}_{4}\right]$ is also very similar to the $\mathrm{NH}_{3}$ ternary homogeneous nucleation case (Benson et al., 2009, 2011).

Figure $2 \mathrm{~b}$ shows results for $\log J$ vs. $\log$ [TMA] for $J$ values between $12-41 \mathrm{~cm}^{-3} \mathrm{~s}^{-1}$ and [TMA] in the range $180-1350$ pptv. The total flow rate in the nucleation reactor was $\sim 5 \mathrm{lpm}$ corresponding to a residence time of $20 \mathrm{~s}$. The slope of $\log J$ vs. Log [TMA] was 0.7, for $\left[\mathrm{H}_{2} \mathrm{SO}_{4}\right]$ at the $10^{7} \mathrm{~cm}^{-3}$ range and $25 \% \mathrm{RH}$. This is again similar to the $\mathrm{NH}_{3}$-THN result, where the slope of $\log J$ vs. $\log \left[\mathrm{NH}_{3}\right]$ was nearly 1 (Benson et al., 2011).

The effect of TMA in particle number concentration was quantitatively characterized by comparing the ratios of particle number concentration with and without TMA as a function of both $\left[\mathrm{H}_{2} \mathrm{SO}_{4}\right]$ and [TMA]. This ratio, defined as the enhancement factor (EF), was found to be dependent on $\left[\mathrm{H}_{2} \mathrm{SO}_{4}\right]$, with higher values at lower $\left[\mathrm{H}_{2} \mathrm{SO}_{4}\right]$ (Fig. 3a). These EF values (2-35) were somewhat higher than those found in $\mathrm{NH}_{3}$ - THN experiments (Benson et al., 2011) un-
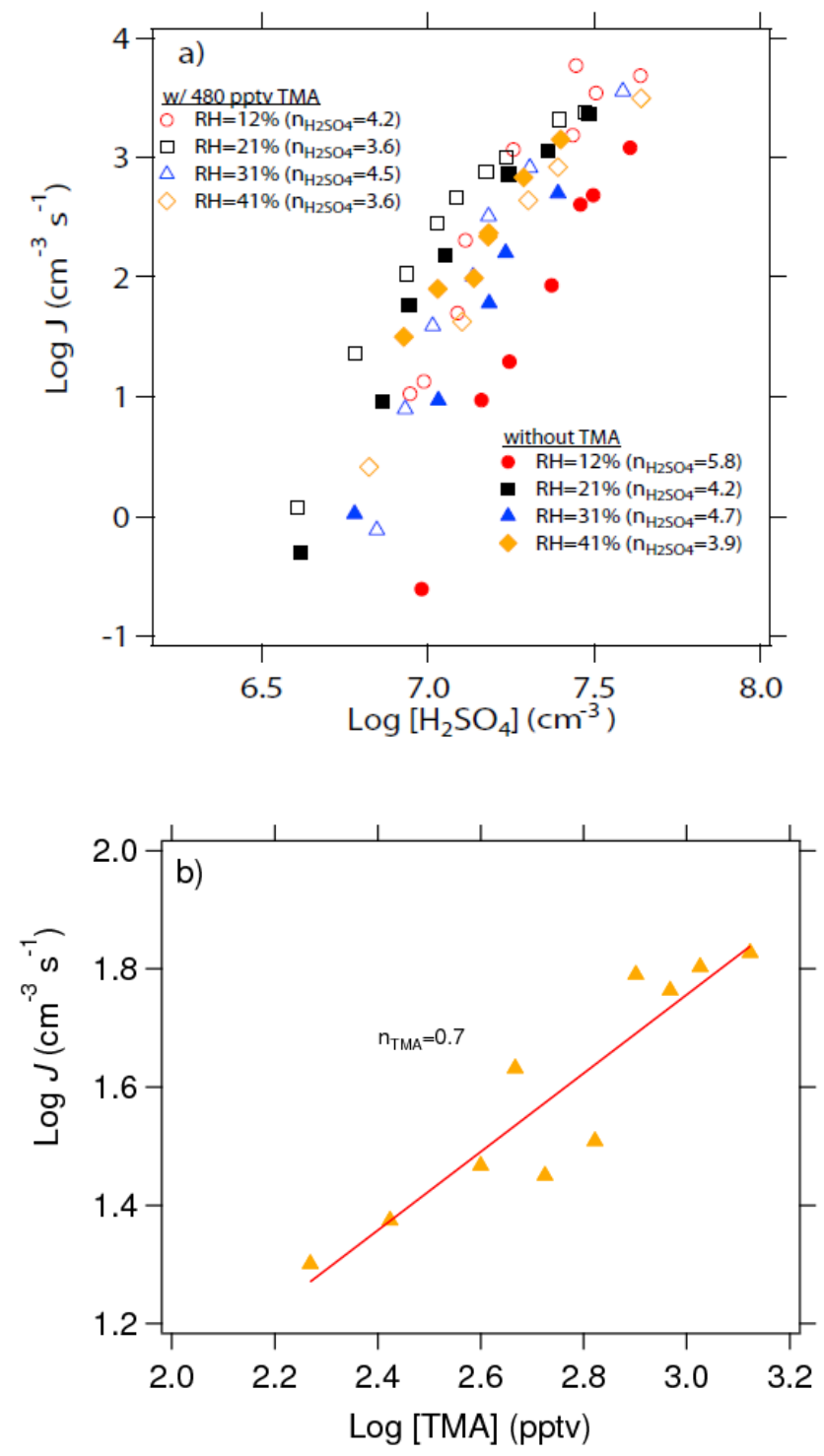

Fig. 2. (a) The measured $\log J$ vs. $\log \left[\mathrm{H}_{2} \mathrm{SO}_{4}\right]$ at $\mathrm{RH}$ of $12-41 \%$ without (filled symbols) and with TMA (480 pptv) (open symbols). The total flow in the reactor was maintained at $2 \mathrm{lpm}$, corresponding to residence time of $\sim 50 \mathrm{~s}$. The range of $\left[\mathrm{H}_{2} \mathrm{SO}_{4}\right]$ was from $5 \times 10^{6}-1 \times 10^{8} \mathrm{~cm}^{-3}$. For clarity, linear fitting lines of the data

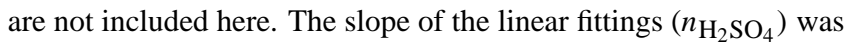
4-6 before adding TMA and 4-5 after adding TMA of 480 pptv. (b) $\log J$ vs. Log [TMA] (180-1350 pptv). The flow rate in the reactor was $5 \mathrm{lpm}$ translating to $\sim 20 \mathrm{~s}$ residence time. The solid line shows the linear fitting of the data and $n=$ TMA indicates the slope.

der similar $\left[\mathrm{H}_{2} \mathrm{SO}_{4}\right]$, but generally lower than the values in (Benson et al., 2009) at higher $\left[\mathrm{H}_{2} \mathrm{SO}_{4}\right]$. The difference in EF between TMA multicomponent nucleation and $\mathrm{NH}_{3}-$ THN could be due to residence times and likely due to the higher basicity of TMA than $\mathrm{NH}_{3}$. The relationship between EF and [TMA] is presented in Fig. 3b. There was also a linear relationship between EF and TMA for [TMA] in the range 

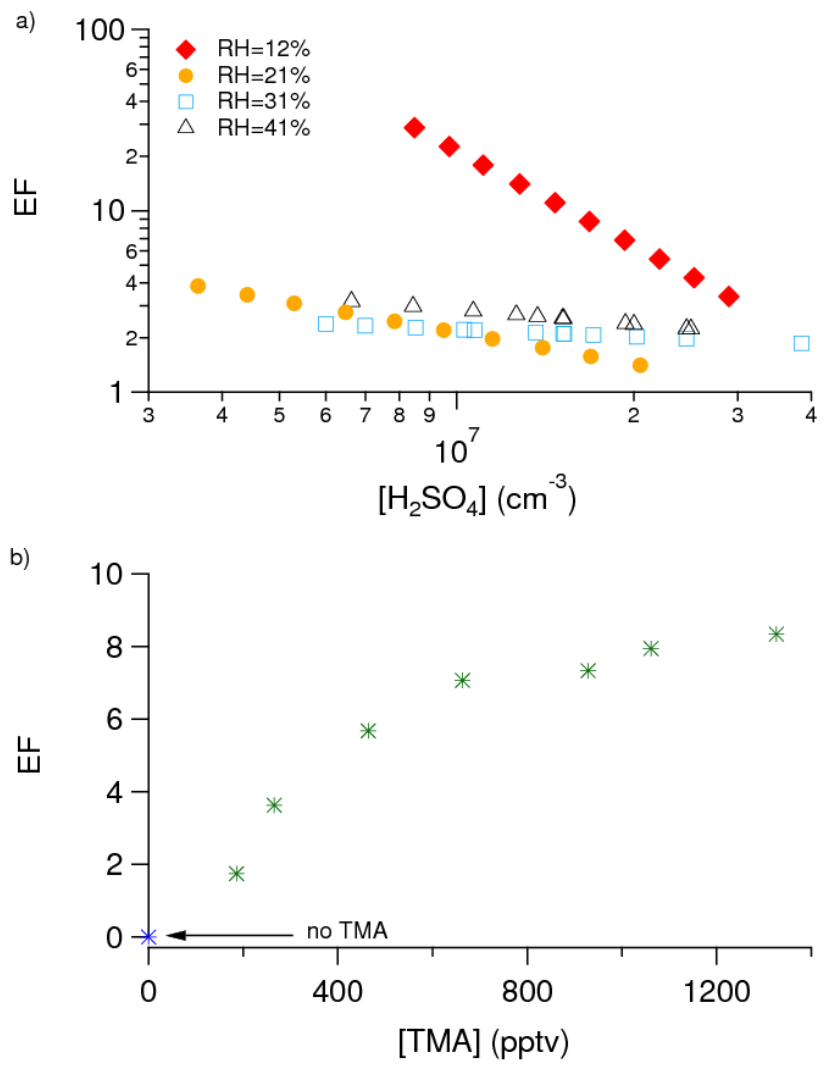

Fig. 3. (a) The measured $\mathrm{EF}$ as a function of $\left[\mathrm{H}_{2} \mathrm{SO}_{4}\right]$ (in the range of $5 \times 10^{6}-6 \times 10^{7} \mathrm{~cm}^{-3}$ ) at $\mathrm{RH}=12 \%$ (red diamonds), $21 \%$ (orange circles), $31 \%$ (light blue squares), and $41 \%$ (black triangles). (b) EF as a function of [TMA] (180-1350 pptv) at $\left[\mathrm{H}_{2} \mathrm{SO}_{4}\right]=1 \times 10^{7} \mathrm{~cm}^{-3}$ and $\mathrm{RH}=25 \%$.

of 180-1350 pptv. However at higher [TMA], the slope appeared to decrease in similar manner to (Berndt et al., 2010), likely because particle concentrations would have saturated at this level in CPC.

\section{Discussion}

While we consider experiments without TMA to be BHN, strictly speaking they are pseudo-BHN because of the presence of $\mathrm{NH}_{3}$ from the humidified air (Benson et al., 2011). In the TMA multicomponent nucleation, additional $\mathrm{NH}_{3}$ impurities may also exist in the TMA permeation tube, as TMA compounds are usually synthesized industrially from $\mathrm{NH}_{3}$ (Ullmann et al., 1996). For these reasons, it is difficult to have $\mathrm{NH}_{3}$-free homogeneous nucleation experiments, and therefore the particle nucleation enhancement reported here and in our $\mathrm{NH}_{3}$-THN studies (Benson et al., 2009, 2011) are somewhat an underestimation. Nevertheless, in the actual atmosphere, $\mathrm{NH}_{3}$ and amines are also usually from the same sources. Under the experimental conditions reported here, we have estimated 400 pptv $\mathrm{NH}_{3}$ (upper limit) in the flow reactor from de-ionized water and TMA together. This is a substantial amount which can enhance particle number concentrations. But as shown in (Benson et al., 2011), at higher $\left[\mathrm{NH}_{3}\right](1.2-2.6 \mathrm{ppbv})$ and under similar $\left[\mathrm{H}_{2} \mathrm{SO}_{4}\right]$ $\left(10^{7} \mathrm{~cm}^{-3}\right)$, RH $(12 \%)$ and residence time $(60 \mathrm{~s})$, the resultant EF $(<2)$ was an order of magnitude lower than the EF from TMA reported here. This higher EF is thus definitely attributed to TMA, which is a stronger base than $\mathrm{NH}_{3}$ and hence can form neutral and ionic clusters more efficiently with $\mathrm{H}_{2} \mathrm{SO}_{4}$ compared to $\mathrm{NH}_{3}$ (Kurtén et al., 2008).

A recent study (Berndt et al., 2010) has shown that a primary amine, tert-butylamine enhances nucleation up to two orders of magnitude more than $\mathrm{NH}_{3}$, at amine concentrations of ppbv or tenth ppbv. This EF is at the same order as that seen in the $\mathrm{NH}_{3}$ study (Benson et al., 2009) at similarly high concentrations of $\mathrm{H}_{2} \mathrm{SO}_{4}$ and $\mathrm{NH}_{3}$. Our results, using much lower $\left[\mathrm{H}_{2} \mathrm{SO}_{4}\right]$ and approximately the same concentrations of TMA, however, show that TMA enhances nucleation at about an order of magnitude lower than in (Berndt et al., 2010). The plausible explanation of this difference is the structure (primary amine, and therefore less steric hindrance) and the higher molecular weight of tert-butylamine than TMA. Laboratory studies have shown that the particle formation potential of amines can vary depending on the molecular structure and experimental conditions (Murphy, 2007).

The role of $\mathrm{RH}$ found in atmospheric observations often contradicts that from laboratory experiments (Laaksonen et al., 2008). In atmospheric observations RH appears to diminish nucleation (Hamed et al., 2011), for example, as shown by much lower NPF frequencies in summer $(<\sim 10 \%)$ than in spring and fall (both > 40\%) (Bonn and Moortgat, 2003; Erupe et al., 2010; Kulmala et al., 2004), while laboratory experiments indicate that RH enhances (Benson et al., 2008, 2009, 2011; Young et al., 2008). In the current experiments, while an increase in $\mathrm{RH}$ appears to enhance $\mathrm{BHN}$ rates like in previous laboratory studies (Benson et al., 2008, 2009; Young et al., 2008), in the presence of TMA the RH effect diminishes at higher RH, consistent with atmospheric observations. Quantum chemical study of dimethylamine has indicated that hydrations of dimethylamine and $\mathrm{NH}_{3}$ are different, as $\mathrm{NH}_{3}$ clusters hydrate more efficiently at higher $\mathrm{RH}$ than dimethylamine (Loukonen et al., 2010). This could in part explain the different $\mathrm{RH}$ dependence of nucleation involving TMA and $\mathrm{NH}_{3}$.

Our observations show that TMA enhances particle nucleation, but $\mathrm{H}_{2} \mathrm{SO}_{4}$ appears to be still the key nucleation precursor even in the presence of high concentrations of TMA (up to1.5 ppbv), consistent with previous observations (Benson et al., 2008, 2009, 2011; Berndt et al., 2005; McMurry et al., 2005; Sipilä et al., 2010; Young et al., 2008). Currently, there are no field studies of amines in a similar manner to the $\mathrm{NH}_{3}-\mathrm{H}_{2} \mathrm{SO}_{4}-\mathrm{H}_{2} \mathrm{O}$ ternary nucleation studies in Atlanta, GA (McMurry et al., 2005) and Kent, OH (Erupe et al., 2010) to test the laboratory experiments. There is also caveat when 
comparing the slopes of $\log J$ vs. $\log \left[\mathrm{H}_{2} \mathrm{SO}_{4}\right]$ values taken from laboratory studies and from field observations, because the former is taken under a constant temperature and constant saturations ratios of water (that is, $\mathrm{RH}$ ) and of other possible ternary species, but the latter is derived from the ensemble data taken at various $\mathrm{RH}$ and temperatures and in the presence of many different chemical species of different saturation ratios. That is, careful laboratory experiments fulfill the assumptions inherent in the 1st nucleation theorem (Kashchiev, 1982; McGraw and Zhang, 2008), but field experiments typically do not follow such assumptions. From these reasons, a direct comparison of slopes taken in the laboratory and derived from field studies is not straightforward.

In some atmospheric conditions, species other than $\mathrm{H}_{2} \mathrm{SO}_{4}$ and $\mathrm{H}_{2} \mathrm{O}$ are also needed to explain aerosol nucleation in the atmosphere, but the identity of the third species which can efficiently enhance nucleation of $\mathrm{H}_{2} \mathrm{SO}_{4}$ is unknown. While $\mathrm{NH}_{3}$ can contribute to $\mathrm{H}_{2} \mathrm{SO}_{4}-\mathrm{H}_{2} \mathrm{O}$ binary nucleation (Ball et al., 1999; Benson et al., 2009, 2011; Weber et al., 1998), organic compounds, such as trimethylbenzene (Metzger et al., 2010) and toluic acid (Zhang et al., 2004) can also enhance aerosol nucleation. Our results of multicomponent nucleation involving TMA provide direct insights into the possible role of amines, in line with some recent studies which showed that amines could play more important roles in $\mathrm{H}_{2} \mathrm{SO}_{4}-\mathrm{H}_{2} \mathrm{O}$ nucleation (Berndt et al., 2010; Kurtén et al., 2008; Loukonen et al., 2010).

\section{Conclusions}

To our knowledge, we provide the first comprehensive laboratory investigation of multicomponent aerosol nucleation involving TMA, as a function of aerosol precursor concentrations. Under $\left[\mathrm{H}_{2} \mathrm{SO}_{4}\right]$ and [TMA] conditions relevant to the lower troposphere, we show that TMA can enhance $\mathrm{H}_{2} \mathrm{SO}_{4}$ $\mathrm{H}_{2} \mathrm{O}$ nucleation but the cutoff $\left[\mathrm{H}_{2} \mathrm{SO}_{4}\right]$ needed for nucleation was surprisingly similar to that in $\mathrm{NH}_{3}-\mathrm{THN}$ (Benson et al., 2011). The slope of $\log J$ vs. $\log \left[\mathrm{H}_{2} \mathrm{SO}_{4}\right]$ was $4-6$ in the absence of TMA, whereas in the presence of TMA, the slope was slightly reduced to $4-5$, depending on RH. The slope of $\log J$ vs. $\log$ [TMA] was only one, similar to $\mathrm{NH}_{3}$ in ternary nucleation. Our results show that TMA enhances nucleation, but the EF was rather moderate, at the conditions relevant to the lower troposphere, also similar to $\mathrm{NH}_{3}$. Amines can contribute significantly to the total budget of atmospheric bases both in continental and marine environments, and in most of atmospheric regions their sources are similar and they co-exist near the source region. Our results, together with (Ball et al., 1999; Benson et al., 2009, 2011; Berndt et al., 2010), strongly imply that the effects of inorganic and organic base gases $\left(\mathrm{NH}_{3}\right.$ and amines such as TMA and tert-butylamine) on nucleation should be taken into account together to improve nucleation theories.
Acknowledgements. This study was supported by NOAA (NA08OAR4310537), NSF (Career ATM-0645567; ATM0904044) and Ohio Board of Regents. We also thank Greg Huey and Dave Tanner for technical support for CIMS; Jyri Mikkilä for technical assistances on PSM; John Passett, Bob Twieg, Li-Hao Young and Dave Moore for useful discussions; and Dave Benson, Andrey Makovich, and Vijay Kanawade for technical assistances; Jason Yu for providing TMA CIMS measurements.

Edited by: A. Laaksonen

\section{References}

Atkinson, R.: Kinetics and mechanisms of the gas-phase reactions of the hydroxyl radical with organic compounds under atmospheric conditions, Chem. Rev., 86(1), 69-201, 1986.

Ball, S. M., Hanson, D. R., Eisele, F. L., and McMurry, P. H.: Laboratory studies of particle nucleation: Initial results for $\mathrm{H}_{2} \mathrm{SO}_{4}$, $\mathrm{H}_{2} \mathrm{O}$, and $\mathrm{NH}_{3}$ vapors, J. Geophys. Res., 104, 23709-23718, 1999.

Barsanti, K. C., McMurry, P. H., and Smith, J. N.: The potential contribution of organic salts to new particle growth, Atmos. Chem. Phys., 9, 2949-2957, doi:10.5194/acp-9-2949-2009, 2009.

Baulch, D. L., Cox, R. A., Crutzen, P. J., Hampson, R. F., and Kerr, J. A.: Evaluated kinetic and photochemical data for atmospheric chemistry: Supplement I, J. Phys. Chem. Ref. Data, 11, 328-496, 1982.

Benson, D. R., Young, L. H., Kameel, R., and Lee, S.-H.: Laboratory-Measured Sulfuric Acid and Water Homogeneous Nucleation Rates from the $\mathrm{SO}_{2}+\mathrm{OH}$ Reaction, Geophys. Res. Lett., 35, L11801, doi:11810.11029/12008GL033387, 2008.

Benson, D. R., Erupe, M. E., and Lee, S.-H.: Laboratorymeasured $\mathrm{H}_{2} \mathrm{SO}_{4}-\mathrm{H}_{2} \mathrm{O}-\mathrm{NH}_{3}$ ternary homogeneous nucleation rates: Initial observations, Geophys. Res. Lett., 36, L15818, doi:10.1029/2009GL038728, 2009.

Benson, D. R., Markovich, A., Al-Refai, M., and Lee, S.-H.: A Chemical Ionization Mass Spectrometer for ambient measurements of Ammonia, Atmos. Meas. Tech., 3, 1075-1087, doi:10.5194/amt-3-1075-2010, 2010.

Benson, D., Markovich, A., and Lee, S.-H.: Ternary homogeneous nucleation of $\mathrm{H}_{2} \mathrm{SO}_{4}, \mathrm{NH}_{3}$, and $\mathrm{H}_{2} \mathrm{O}$ under conditions relevant to the lower troposphere, Atmos. Chem. Phys., 11, 4755-4766, doi:10.5194/acp-11-4755-2011, 2011.

Berndt, T., Boge, O., Stratmann, F., Heintzenberg, J., and Kulmala, M.: Rapid formation of sulfuric acid particles at near atmospheric conditions, Science, 307, 671-698, 2005.

Berndt, T., Stratmann, F., Sipilä, M., Vanhanen, J., Petäjä, T., Mikkil, J., Grüner, A., Spindler, G., Lee Mauldin III, R., Curtius, J., Kulmala, M., and Heintzenberg, J.: Laboratory study on new particle formation from the reaction $\mathrm{OH}+\mathrm{SO}_{2}$ : influence of experimental conditions, $\mathrm{H}_{2} \mathrm{O}$ vapour, $\mathrm{NH}_{3}$ and the amine tert-butylamine on the overall process, Atmos. Chem. Phys., 10, 7101-7116, doi:10.5194/acp-10-7101-2010, 2010.

Bonn, B. and Moortgat, G. K.: Sesquiterpene ozonolysis: Origin of atmospheric new particle formation from biogenic hydrocarbons, Geophys. Res. Lett., 30(11), 1585, doi:1510.1029/2003GL017000, 2003. 
Bzdek, B. R., Ridge, D. P., and Johnston, M. V.: Amine exchange into ammonium bisulfate and ammonium nitrate nuclei, Atmos. Chem. Phys., 10, 3495-3503, doi:10.5194/acp-10-3495-2010, 2010.

Cadle, S. and Mulawa, P.: Low-molecular-weight aliphatic amines in exhaust from catalyst-equipped cars, Environ. Sci. Technol., 14(6), 718-723, 1980.

Cantrell, C. A., Zimmer, A., and Tyndell, G. S.: Absorption cross sections for water vapor from 183 to $193 \mathrm{~nm}$, J. Geophys. Lett., 24, 2195-2198, 1997.

Eisele, F. L. and Tanner, D. J.: Measurements of gas phase concentrations of $\mathrm{H}_{2} \mathrm{SO}_{4}$ and methane sulfonic acid and estimates of $\mathrm{H}_{2} \mathrm{SO}_{4}$ production and loss in the atmosphere, J. Geophys. Res., 98, 9001-9010, 1993.

Erupe, M. E., Benson, D. R., Li, J., Young, L.-H., Verheggen, B., Al-Refai, M., Tahboub, O., Cunningham, V., Frimpong, F., Viggiano, A. A., and Lee, S.-H.: Correlation of Aerosol Nucleation Rate with Sulfuric Acid and Ammonia in Kent Ohio: An Atmospheric Observation, J. Geophys. Res., 115, D23216, doi:10.1029/2005GL023268, 2010.

Facchini, M., Decesari, S., Rinaldi, M., Carbone, C., Finessi, E., Mircea, M., Fuzzi, S., Moretti, F., Tagliavini, E., and Ceburnis, D.: Important source of marine secondary organic aerosol from biogenic amines, Environ. Sci. Technol., 42(24), 91169121, 2008.

Finlayson-Pitts, B. J. and Pitts, J. N.: Chemistry of the Upper and Lower Atmosphere: Theory, Experiments, and Applications, Academic Press, San Diego, CA, 2000

Ge, X., Wexler, A. S., and Clegg, S. L.: Atmospheric amines - Part I., A review, Atmos. Environ., 45(3), 524-546, 2010 a.

Ge, X., Wexler, A. S., and Clegg, S. L.: Atmospheric amines Part II., Thermodynamic properties and gas/particle partitioning, Atmos. Environ., 45(3), 561-577, 2010b.

Gibb, S. W., Mantoura, R. F. C., and Liss, P. S.: Ocean-atmosphere exchange and atmospheric speciation of ammonia and methylamines in the region of the NW Arabian Sea, Global Biogeochem. Cy., 13(1), 161-178, 1999.

Hoffmann, T., Bandur, R., Marggraf, U., and Linscheid, M.: Molecular composition of organic aerosols formed in the $\alpha$-pinene $/ \mathrm{O}_{3}$ reaction: implications for new particle formation processes, J. Geophys. Res., 103, 25569-25578, 1998.

Hyvarinen, A., Lihavainen, H., Hautio, K., Raatikainen, T., Viisanen, Y., and Laaksonen, A.: Surface tensions and densities of sulfuric acid + dimethylamine + water solutions, J. Chem. Eng. Data, 49(4), 917-922, 2004.

Hyvärinen, A., Raatikainen, T., Laaksonen, A., Viisanen, Y., and Lihavainen, $\mathrm{H}$.: Surface tensions and densities of $\mathrm{H}_{2} \mathrm{SO}_{4}+\mathrm{NH}_{3}+$ water solutions, Geophys. Res. Lett., 32(16), L16806, doi:10.1029/2005GL023268, 2005.

IPCC: Climate Change 2007: The Physical Science Basis, Cambridge University Press, New York, NY, 2007.

Kashchiev, D.: On the relation between nucleation work, nucleus size, and nucleation rate, J. Phys. Chem., 76, 5098-5012, 1982.

Kavouras, I. G., Mihalopoulos, N., and Stephanou, E. G.: Formation of atmospheric particles from organic acids produced by forests, Nature, 395, 683-686, 1998.

Keesee, R. G. and Castleman, A. W.: Thermochemical Data on Gas-Phase Ion-Molecule Association and Clustering Reactions, J. Phys. Chem. Ref. Data, 15, 1011, doi:10.1063/1.555757, 1986.
Koch, R., Krüger, H. U., Elend, M., Palm, W. U., and Zetzsch, C.: Rate constants for the gas-phase reaction of $\mathrm{OH}$ with amines: tert-Butyl amine, 2,2,2-Trifluoroethyl amine, and 1,4Diazabicyclo[2.2.2] octane, Int. J. Chem. Kin., 28(11), 807-815, 1996.

Kulmala, M., Vehkamaki, H., Petaja, T., dal Maso, M., Lauri, A., Kerminen, V. M., Birmili, W. H., and McMurry, P. H.: Formation and growth rates of ultrafine atmospheric particles: A review of observations, J. Aerosol Sci., 35, 143-176, 2004.

Kurtén, T., Loukonen, V., Vehkamäki, H., and Kulmala, M.: Amines are likely to enhance neutral and ion-induced sulfuric acid-water nucleation in the atmosphere more effectively than ammonia, Atmos. Chem. Phys., 8, 4095-4103, doi:10.5194/acp8-4095-2008, 2008.

Laaksonen, A., Kulmala, M., Berndt, T., Stratmann, F., Mikkonen, S., Ruuskanen, A., Lehtinen, K. E. J., Dal Maso, M., Aalto, P., Petäjä, T., Riipinen, I., Sihto, S.-L., Janson, R., Arnold, F., Hanke, M., Ücker, J., Umann, B., Sellegri, K., O’Dowd, C. D., and Viisanen, Y.: $\mathrm{SO}_{2}$ oxidation products other than $\mathrm{H}_{2} \mathrm{SO}_{4}$ as a trigger of new particle formation. Part 2: Comparison of ambient and laboratory measurements, and atmospheric implications, Atmos. Chem. Phys., 8, 7255-7264, doi:10.5194/acp-8-7255-2008, 2008.

Loukonen, V., Kurtén, T., Ortega, I. K., Vehkamäki, H., Pádua, A. A. H., Sellegri, K., and Kulmala, M.: Enhancing effect of dimethylamine in sulfuric acid nucleation in the presence of water - a computational study, Atmos. Chem. Phys., 10, 4961-4974, doi:10.5194/acp-10-4961-2010, 2010.

Makela, J. M., Yli-Koivisto, S., Hiltunen, V., Seidl, W., Swietlicki, E., Teinila, K., Sillanpaa, M., Koponen, I. K., Paatero, J., Rosman, K., and Hameri, K.: Chemical Composition of Aerosol During Particle Formation Events in Boreal Forest, Tellus B, 53, 380-393, 2001.

Malloy, Q. G. J., Li Qi, Warren, B., Cocker III, D. R., Erupe, M. E., and Silva, P. J.: Secondary organic aerosol formation from primary aliphatic amines with $\mathrm{NO}_{3}$ radical, Atmos. Chem. Phys., 9, 2051-2060, doi:10.5194/acp-9-2051-2009, 2009.

McGraw, R. and Zhang, R.: Multivariate analysis of homogeneous nucleation rate measurements. Nucleation in the p-toluic acid/sulfuric acid/water system, J. Chem. Phys., 128, 064508, doi:10.1063/1.2830030, 2008.

McMurry, P. H., Fink, M., Sakuri, H., Stolzenburg, M., Mauldin III, R. L., Smith, J., Eisele, F. L., Moore, K., Sjostedt, S., Tanner, D., Huey, L. G., Nowak, J. B., Edgerton, E., and Voisin, D.: A criterion for new particle formation in the sulfur-rich Atlanta atmosphere, J. Geophys. Res., 110, D22S02, doi:10.1029/2005JD005901, 2005.

Merikanto, J., Napari, I., Vehkamäki, H., Anttila, T., and Kulmala, M.: New parameterization of sulfuric acid-ammonia-water ternary nucleation rates at tropospheric conditions, J. Geophys Res., 112, D15207, doi:15210.11029/12006JD007977, 2007.

Merikanto, J., Spracklen, D. V., Mann, G. W., Pickering, S. J., and Carslaw, K. S.: Impact of nucleation on global CCN, Atmos. Chem. Phys., 9, 8601-8616, doi:10.5194/acp-9-8601-2009, 2009.

Metzger, A., Verheggen, B., Dommen, J., Duplissy, J., Prevot, A. S. H., Weingartner, E., Riipinen, I., Kulmala, M., Spracklen, D. V., Carslaw, K. S., and Baltensperger, U.: Evidence for the role of organics in aerosol particle formation under 
atmospheric conditions, P. Natl. Acad. Sci. USA, 107, 6646, doi:10.1073/pnas.0911330107, 2010.

Murphy, S. M., Sorooshian, A., Kroll, J. H., Ng, N. L., Chhabra, P., Tong, C., Surratt, J. D., Knipping, E., Flagan, R. C., and Seinfeld, J. H.: Secondary aerosol formation from atmospheric reactions of aliphatic amines, Atmos. Chem. Phys., 7, 2313-2337, doi:10.5194/acp-7-2313-2007, 2007.

NIST: NIST Standard Reference Database Number 69, edited, National Institute for Standard Technology (NIST) Chemistry Web Book, 2005.

Nowak, J. B., Huey, L. G., Eisele, F. L., Tanner, D., Mauldin III, R. L., Cantrell, C. A., Kosciuch, E., and Davis, D.: ( Chemical ionization mass spectrometry technique for the detection of dimethylsulfoxide and ammonia, J. Geophys. Res., 107(D18), 4363, doi:4310.1029/2001JD001058, 2002.

Nowak, J. B., Huey, L. G., Russell, A. G., Tian, D., Neuman, J. A., Orsini, D., Sjostedt, S. J., Sullivan, A. P., Tanner, D. J., Weber, R. J., Nenes, A., Edgerton, E., and Fehsenfeld, F. C.: Analysis of urban gas phase ammonia measurements from the 2002 Atlanta Aerosol Nucleation and Real-Time Characterization Experiment (ANARChE), J. Geophys. Res., 111, D17308, doi:17310.11029/12006JD007113, 2006.

Nowak, J. B., Newman, J. A., Kozai, K., Huey, L. G., Tanner, D., Holloway, J. S., Ryerson, T. B., Frost, G. L., McKeen, S. A., and Fehsenfeld, F. C.: A chemical ionization mass spectrometry technique for airborne measurements of ammonia, J. Geophys. Res., 112, D10S02, doi:10.1029/2006JD007589, 2007.

O’Dowd, C. D., Hameri, K., Makela, J., Vakeva, M., Aalto, P., de Leeuw, G., Kunz, G. J., Becker, E., Hansson, H.-C., Allen, A. G., Harrison, A. M., Berresheim, H., Kleefeld, C., Geever, M., Jennings, S. G., and Kulmala, K.: Atmospheric particles from organic vapors, Nature, 416, 497-498, 2002.

Paasonen, P., Nieminen, T., Asmi, E., Manninen, H. E., Petäjä, T., Plass-Dülmer, C., Flentje, H., Birmili, W., Wiedensohler, A., Hõrrak, U., Metzger, A., Hamed, A., Laaksonen, A., Facchini, M. C., Kerminen, V.-M., and Kulmala, M.: On the roles of sulphuric acid and low-volatility organic vapours in the initial steps of atmospheric new particle formation, Atmos. Chem. Phys., 10, 11223-1242, doi:10.5194/acp-10-11223-2010, 2010.

Pitts Jr., J., Grosjean, D., Van Cauwenberghe, K., Schmid, J., and Fitz, D.: Photooxidation of aliphatic amines under simulated atmospheric conditions: formation of nitrosamines, nitramines, amides, and photochemical oxidant, Environ. Sci. Technol., 12(8), 946-953, 1978.

Riipinen, I., Sihto, S.-L., Kulmala, M., Arnold, F., Dal Maso, M., Birmili, W., Saarnio, K., Teinilä, K., Kerminen, V.-M., Laaksonen, A., and Lehtinen, K. E. J.: Connections between atmospheric sulphuric acid and new particle formation during QUEST IIIIV campaigns in Heidelberg and Hyytil, Atmos. Chem. Phys., 7, 1899-1914, doi:10.5194/acp-7-1899-2007, 2007.

Schade, G. W. and Crutzen, P. J.: Emissions of aliphatic amines from animal husbandry and their reactions: Potential source of $\mathrm{N}_{2} \mathrm{O}$ and HCN, J. Atmos. Chem., 22, 319-346, 1995.

Silva, P. J., Erupe, M., Warren, B., and Li, Q.: Trimethylamine as precursor to secondary organic aerosol formation via nitrate radical reaction in the atmosphere, Environ. Sci. Technol., 42(13), 4689-4696, 2008.

Sipilä, M., Berndt, T., Petaja, T., Brus, D., Vanhanen, J., Stratmann, F., Patokoski, J., Mauldin III, R. L., Hyvarinen, A.-P.,
Lihavainen, H., and Kulmala, M.: The Role of Sulfuric Acid in Atmospheric Nucleation, Science, 327, 1243-1246, 2010.

Smith, J. N., Moore, K. F., McMurry, P. H., and Eisele, F. L.: Atmospheric measurements of sub $20 \mathrm{~nm}$ diameter particle chemical composition performed using Thermal Desorption Chemical Ionization Mass Spectrometry, Aerosol Sci. Tech., 38, 100-110, 2004.

Smith, J. N., Moore, K., Eisele, F. L., Voisin, D., Ghimire, A. K., Sakuri, H., and McMurry, P. H.: Chemical composition of atmospheric nanoparticles during nucleation in Atlanta, J. Geophys. Res., 110, D22S03, doi:10.1029/2005JD005912, 2005.

Smith, J. N., Dunn, M. J., VanReken, T. M., Iida, K., Stolzenburg, M. R., McMurry, P. H., and Huey, L. G.: Chemical composition of atmospheric nanoparticles formed from nucleation in Tecamac, Mexico: Evidence for an important role for organic species in nanoparticle growth, Geophys. Res. Lett., 35, L04808, doi:04810.01029/02007GL032523, 2008.

Smith, J. N., Barsanti, K. C., Friedli, H. R., Ehn, M., Kulmala, M., Collins, D. R., Scheckman, J. H., Willians, B. J., and McMurry, P. H.: Observations of amonium salts in atmospheric nanoparticles and possible climatic implications, P. Natl. Acad. Sci. USA, 107, 6634-6639, doi:10.1073/pnas.0912127107, 2010.

Sorooshian, A., Murphy, S. M., Hersey, S., Gates, H., Padro, L. T., Nenes, A., Brechtel, F. J., Jonsson, H., Flagan, R. C., and Seinfeld, J. H.: Comprehensive airborne characterization of aerosol from a major bovine source, Atmos. Chem. Phys., 8, 5489-5520, doi:10.5194/acp-8-5489-2008, 2008.

Ullmann, F.: Ullmann's encyclopedia of industrial chemistry, VCH New York, doi:10.1002/14356007, 1996.

Vehkamäki, H., Kulmala, M., Napari, I., Lehtinen, E. J., Timmreck, C., Noppel, M., and Laaksonen, A.: An improved parameterization for sulfuric acid-water nucleation rates for tropospheric and stratospheric conditions, J. Geophys. Res., 107, 4622, doi:4610.1029/2002JD002184, 2002.

Viggiano, A. A., Seeley, J. V., Mundis, J. S., Williamson, J. S., and Morris, R. A.: Stratospheric negative ion reaction rates with $\mathrm{H}_{2} \mathrm{SO}_{4}$, J. Geophys. Res., 87, 7340-7342, 1982.

Wang, L., Khalizov, A., Zheng, J., Xu, W., Ma, Y., Lal, V., and Zhang, R.: Atmospheric nanoparticles formed from heterogeneous reactions of organics, Nat. Geosci., 3, 238-242, 2010 a.

Wang, L., Lal, V., Khalizov, A., and Zhang, R.: Heterogeneous Chemistry of Alkylamines with Sulfuric Acid: Implications for Atmospheric Formation of Alkylaminium Sulfates, Environ. Sci. Technol., 44(7), 2461-2465, 2010 b.

Weber, R. J., Marti, J. J., McMurry, P. H., Mauldin III, R. L., Tanner, D., Eisele, F. L., Brechtel, F., Kreidenweis, S. M., Kok, G., Schillawski, R. D., and Baumgardner, D.: A study of new particle formation and growth involving biogenic and trace gas species measured during ACE 1, J. Geophys. Res., 103, 1638516396, 1998.

Weber, R. J., McMurry, P. H., Mauldin III, R. L., Tanner, D., Eisele, F. L., Clarke, A. D., and Kapustin, V. N.: New particle formation in the remote troposphere: A comparison of observations at various sites, Geophys. Res. Lett., 26, 307-310, 1999.

Yokelson, R. J., Christian, T. J., Bertschi, I. T., and Hao, W. M.: Evaluation of adsorption effects on measurements of ammonia, acetic acid, and methanol, J. Geophys. Res., 108(D20), 4649, doi:10.1029/2003jd003549, 2003.

Young, L. H., Benson, D. R., Kameel, F. R., Pierce, J. R., 
Junninen, H., Kulmala, M., and Lee, S.-H.: Laboratory studies of $\mathrm{H}_{2} \mathrm{SO}_{4} / \mathrm{H}_{2} \mathrm{O}$ binary homogeneous nucleation from the $\mathrm{SO}_{2}+\mathrm{OH}$ reaction: evaluation of the experimental setup and preliminary results, Atmos. Chem. Phys., 8, 4997-5016, doi:10.5194/acp-8-4997-2008, 2008.
Zhang, R., Suh, J., Zhao, J., Zhang, D., Fortner, E. C., Tie, X., Molina, M. T., and Molina, M., J.: Atmospheric new particle formation enhanced by organic acids, Science, 304, 1487-1490, 2004. 